\title{
下水污泥の熱分解挙動と 生成物の組成・発熱量に関する研究
}

\author{
大下 和徹 ${ }^{*}$ ・森 彰宏 ${ }^{2} \cdot$ 高岡 昌輝 ${ }^{1} \cdot$ \\ 武田 信生 ${ }^{3} \cdot$ 松本 忠生 ${ }^{1} \cdot$ 北山 憲 $^{4}$ \\ 1京都大学大学院 工学研究科都市環境工学専攻 ( $\bar{T} 615-8540$ 京都市西京区京都大学桂) \\ * E-mail: kazu_oshita@mbox.kudpc.kyoto-u.ac.jp \\ 2月島機械株式会社 産業事業本部 プラント計画部（† 104-0051 東京都中央区佃二丁目 17-15） \\ 3 立命館大学 エコ・テクノロジー研究センター（５ 525-8577 滋賀県草津市野路東 1-1-1） \\ ${ }^{4}$ 大阪府 都市整備部（ $=540-8570$ 大阪市中央区大手前二丁目）
}

\begin{abstract}
下水污泥の燃料化として, 熱分解を用いた炭化, あるいはガス化処理が研究・開発されているが，これ らは, 回収熱量, 立地条件などの観点から, 適切に選択する必要がある. そこで, まず本研究では污泥の 熱分解温度が生成物組成, 発熱量に与える影響を定量的に明らかにすることを目的とした.

乾燥ケーキ熱分解実験の結果, 熱分解残渣としては, $300^{\circ} \mathrm{C} て ゙$ 乾燥ケーキ低位発熱量の約 $70 \%$ を回収でき るが, $500^{\circ} \mathrm{C}$ 以上では収率と低位発熱量がともに減少するため, 燃料利用としては $300^{\circ} \mathrm{C} に$ 比較して不利と

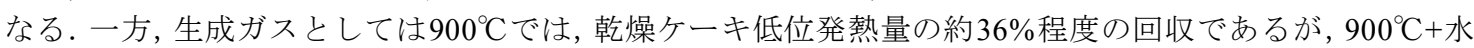
蒸気の条件では, $\mathrm{CO}, \mathrm{H}_{2}$ の生成量増加により, 約 $50 \%$ の回収が見込めることがわかった.
\end{abstract}

Key Words : sewage sludge, carbonization, gasfication, pyrolysis, heating value

\section{1.はじめに}

下水污泥は国内で発生する産業廃棄物のうち $18 \%$ を占め, 埋立地逼迫の観点から, 減容化や有効利用 が重要とされる。 また, 下水污泥は, 量・質ともに 安定したバイオマスとしても位置づけられ, 地球温 暖化防止の観点からは, 下水污泥中の有機分のエネ ルギー利用のさらなる推進が求められるようになっ てきた ${ }^{1)}$.

下水污泥のエネルギー利用には, 近年, 炭化処理, あるいはガス化処理として, 污泥を還元雰囲気下で 熱分解し, 熱分解残渣, あるいは生成ガスを燃料と して利用する方式が研究されてきている，炭化は 250 $\sim 350^{\circ} \mathrm{C}$ の比較的低温域で熱分解し, 熱分解残渣を石 炭火力発電用の燃料として利用する試みであり ${ }^{21}$, ガス化は $800^{\circ} \mathrm{C}$ 以上の比較的高温域で熱分解, さらに は水蒸気などを添加して改質し, 生成されるガスを 発電に利用しようとする試みであって ${ }^{3)}$, 4)，それぞれ の目的に応じた温度域で研究・評価がなされている。

このような熱分解を用いた二つの燃料化手法が研 究されてきている状況で, 効率的に下水污泥のエネ ルギー利用を進めていくには，これらの技術を，回
収熱量, 立地条件, 投入エネルギー, 有害物質の挙 動などの観点から位置づけ, 従来の焼却技術との比 較を行った上で, 適切に選択していか称ばならない. そのためには，まず，同様の下水污泥を用い，低 温域から高温域までの広い温度範囲での熱分解挙動 やそれに伴う様々な元素挙動の把握に加えて, 発生 する熱分解残渣, 水分, タール分, および生成ガス の性状, 量に加え, 特に発熱量が熱分解温度に依存 してどのように分配されるのか, 定量的な評価を行 う必要があるが，あまりそのような評価はなされて いない.

下水污泥を石炭火力発電用の燃料として利用する には, 乾燥污泥を用いるケースもあり, 下水污泥の 有するエネルギーを確保する観点では望ましいが， 受け入れ先や, 乾燥污泥のハンドリングを考慮した 場合, 臭気が最も大きな問題となる ${ }^{2)}$. この課題を克 服するための技術が炭化, 特に低温度域での炭化で あるが，それゆえに，燃料化污泥の発生量や，その 発熱量の分配が重要となる.またガス化においては, 生成ガスは可燃成分を多く含むため, ガス化発電を 行う場合は, 通常, 後段のガスタービンもしくはガ スエンジンにて発電に用いられる. ガス化発電を行 
わない場合においても，生成ガスは燃焼させ，燃焼 熱を熱分解炉に利用することがなされる。 したがっ て, それらの設計や解析のためには, ガス生成量や, 発熱量を明らかにすることが重要となる.

そこで本研究は，下水污泥を対象に，熱分解温度 が生成物 ( 熱分解残渣, 水分, タール分, 生成ガス) の量, 組成に加えて, 特に発熱量に与える影響を定 量的に明らかにすることを目的とした.

具体的には, $300^{\circ} \mathrm{C} \sim 900^{\circ} \mathrm{C}$ 温度範囲, さらに $900^{\circ} \mathrm{C}$ では水蒸気を添加した場合の下水污泥熱分解実験を 行い, 得られる熱分解残渣や，水分，タール分，生 成ガスの収率を明らかにして熱分解挙動を確認する とともに，熱分解温度や水蒸気の添加が，それらの 成分組成，および発熱量に与える影響を明らかにし た。

\section{2. 実験方法}

\section{(1) 対象試料}

熱分解実験を行うためには，下水污泥の脱水ケー キが必要となるが，脱水ケーキの含水率や，脱水助 剂の添加率には変動がともなう。また，脱水前の混 合濃縮污泥は, 初沈濃縮污泥 ( 重力濃縮) と余剒濃縮 污泥 ( 重力濃縮後, 遠心濃縮 ) が混合されたものであ るが，この混合比率も季節や，時間により異なって くる.

そこで，対象試料は，合流式流域下水道の終末処 理場である大阪府寝屋川北部鴻池水みらいセンター にて，初沈濃縮污泥と余㮃濃縮污泥をそれぞれ 20L ず つサンプリングし，両者を固形物比で $1: 1$ となるよう 混合したもの $(\mathrm{TS}:$ 約 $25,000 \mathrm{mg} / \mathrm{L})$ を用意した. 熱分解 実験には，この污泥を一定の条件で脱水・乾燥させ
得られた乾燥厅ーキを用いた。脱水操作に関しては, まず污泥に高分子凝集剤としてカチオンポリマー (CP-401P : KUBOX製)を污泥TSに対して0.87\%添加し, ジャーテスタ (MJS-4 : 宮本製作所製) で 60rpm，30〜 $40 \mathrm{sec}$ 攪拌させ，フロックを形成させた。 その後，ベ ルトプレス脱水を想定した簡易脱水試験機 (BPテス ター：クボタ製) を使用して最大 $4 \mathrm{~kg} / \mathrm{cm}^{2}$ で加圧し脱 水を行った。乾燥操作に関しては, 得られた脱水

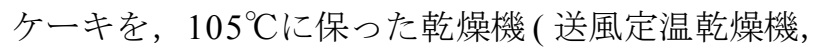
SR-1：増田医科器械製) 中で $15 \mathrm{~h}$ 程度乾燥させ，乾燥 ケーキとした。乾燥ケーキは, 乳鉢で粗破砕し, そ の後できるだけ粒径 $1 \mathrm{~mm}$ 以下の微細な粒子が発生し ないようにはさみを用いて調整した。最終的に，真 鍮製の JIS 試験用ふるい（公称目開き：1mm，2.5mm） を用いて分級したものを熱分解実験の試料とし，こ の際，わずかに発生した粒径 $1 \mathrm{~mm}$ 以下の微細な粒子 は無視した。

\section{(2) 実験装置}

図 -1 に本研究で用いた熱分解実験装置の概略図を 示す. 本実験装置は, 雰囲気ガス供給部分, 石英ガ ラス製の流通管 (内径 $22 \mathrm{~mm}$ ，全長 $600 \mathrm{~mm}$ ) と電気炉か らなる熱分解反応部分, 実験にて発生する水分, タール分 (以下，あわせて液体成分とする。) の捕 集部分, および生成ガスの捕集部分から構成される.

雰囲気ガスは，高純度窒素ガス $\left(\mathrm{N}_{2}-\mathrm{ZERO}\right.$ : 住友精 化製) をマスフローコントローラ (MC-1A : コフロッ ク製) を用いて所定量供給した。 また，実機のガス化 炉では熱分解あるいはガス改質を促進させるために 水蒸気を吹き込むケースも想定されることから ${ }^{4)}$, マントルヒーターで $75^{\circ} \mathrm{C}$ に保温した蒸留水入りのイ ンピンジャーを通過させることにより，水蒸気を雾 囲気ガス中に添加できるようにした。

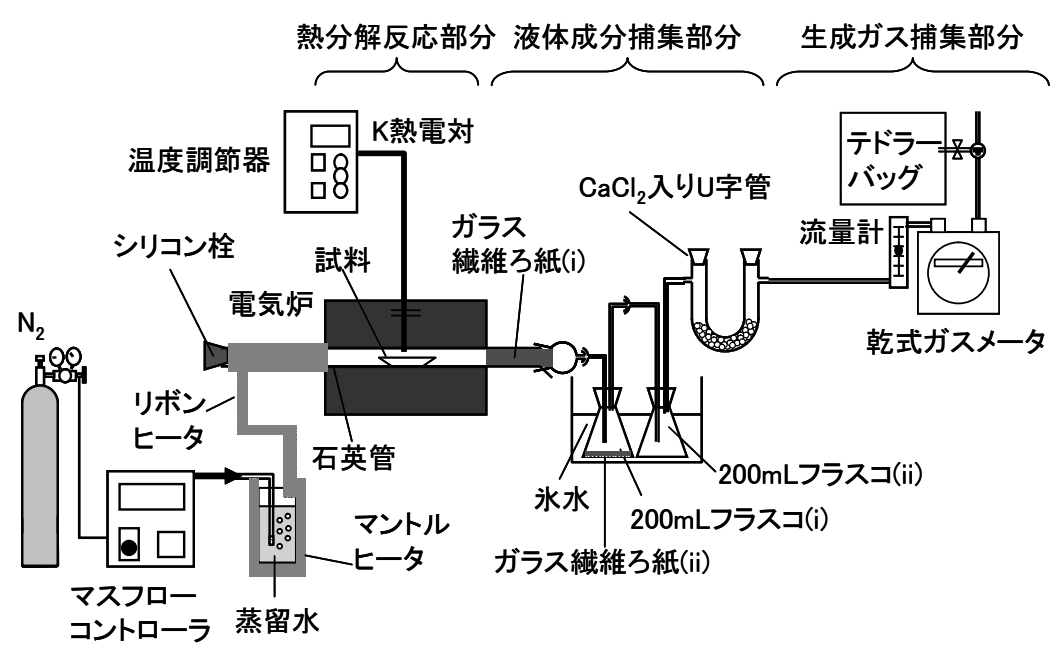

図-1 熱分解実験装置 
流通管の加熱には電気炉 (H717 : 中村科学器械工業 製)を用いた。温度制御は流通管の両端から $300 \mathrm{~mm} の$ 部分において，流通管外壁部に設置した $\mathrm{K}$ 熱電対と， プログラム温度調節器(SS-K-1200: いすぐ製作所製)に よって行った.

液体成分は，まず流通管下流部分にガラス繊維ろ 紙(i)(GA-100：ADVANTEC製)を設置するとともに，水 冷した 2 つの $200 \mathrm{~mL}$ フラスコ (i), (ii) および塩化カル シウムを充填したU 字管を通じて凝縮する液体成分 を捕集した。 また，上流側の $200 \mathrm{~mL}$ フラスコ (i) の底 部にはガラス繊維ろ紙(ii)(GA-100:ADVANTEC製)を設 置した。

液体成分を凝縮させた後の生成ガスは，流量計に よって生成ガス流量を測定するとともに，乾式ガス メータ (modelDC-1：シナガワ製) を通じて生成ガス総 量を把握した上で，テドラーバッグで捕集した。

\section{（3） 熱分解実験条件と実験操作}

熱分解温度は $300^{\circ} \mathrm{C}, 500^{\circ} \mathrm{C}, 700^{\circ} \mathrm{C}, 900^{\circ} \mathrm{C}, 900^{\circ} \mathrm{C}+$ 水蒸気の 5 点とし, 1 条件で 2 回の実験を行った.

熱分解実験操作は次の手順で行った。まず乾燥 ケーキ $1.2 \mathrm{~g}$ をアルミナボートに長さ $60 \mathrm{~mm}$ 程度となる ように乗せ，流通管の電気炉上流部に設置し，流通 管のシリコン栓にて密栓した。 次に高純度窒素ガス をマスフローコントローラにより流量が $100 \mathrm{~mL} / \mathrm{min}$ と なるよう調節して流し，同時に電気炉の昇温を開始 した，所定の温度に達したことと，装置全体を十分 に窒素置換するため窒素流通開始から 60min 以上経 過したことを確認してから，シリコン栓を開けて試 料を電気炉の中心部分に移動させ，すばやくシリコ ン栓を閉じて熱分解を開始させた。シリコン栓を閉 じた時刻を熱分解開始時刻として，生成ガス量を記 録した. $30 \mathrm{~min}$ 経過後に電気炉を止め，上部を開放し 流通管と試料を冷却して熱分解を停止させたが，装
置内部に帯留している生成ガスを完全にテドラー バッグに送るため，停止後も 10 〜 $4 \mathrm{~min}$ 窒素ガスを 流通させ続けた後，実験を終了した。

なお， $900^{\circ} \mathrm{C}+$ 水蒸気の条件では，あらかじめブラ ンク試験を行って，水蒸気吹き込み量を算出した結 果, $162 \sim 184 \mathrm{~g} / \mathrm{m}^{3}{ }_{\mathrm{N}}$ であり, $1.2 \mathrm{~g}$ の乾燥ケーキに対し て重量比で $42 ４ 9 \%$ の水蒸気を吹き込んでいること を確認した。

\section{(4) 分析項目と分析方法}

乾燥ケーキ，熱分解実験後の熱分解残渣，液体成 分, および生成ガスそれぞれについて，表-1に示し た項目の分析を行った. 以下では，それぞれの分析 方法について述べる.

\section{a) 乾燥ケーキ, 熱分解残渣}

まず，実験終了後，熱分解残渣の重量を測定した。 乾燥ケーキと熱分解残渣において, 含水率は下水試 験方法に従って測定した ${ }^{5)}$. 強熱残留物は下水試験 方法5)での然焼温度である $600^{\circ} \mathrm{C}$ ではなく $900^{\circ} \mathrm{C}$ と， 灰分として定めた。これは熱分解温度条件の最大を $900^{\circ} \mathrm{C}$ に設定していることと, 通常 $900^{\circ} \mathrm{C}$ で分析する $\mathrm{CHN}$ 組成分析との対応をとるためである. CHN 組成 分析は, 各試料を分析前に微粉末状にして $105^{\circ} \mathrm{C} て ゙ 一$ 昼夜乾燥させ，CHN コーダ (MT-2 : 柳本製作所製) で 測定した. 1 試料につき 2 回測定を行った.

発熱量の測定にはボンブ断熱熱量計 (OSK150：小川 サンプリング製) を用いた。熱量計の水当量の算出 には熱量標準安息香酸 ((財) 日本品質保証機構製) を 用いた。試料は測定前に乳鉢を用いて粉砕し，微粉 末状にした物を用いた。低位発熱量の算出には含水 率および水素含有量の值を用いて式(1)によって算出 した6).

$$
H_{U}=H_{O}-2.512(9 h+w) / 100
$$

表-1 分析項目

\begin{tabular}{|c|c|c|c|c|c|c|}
\hline & \multirow{2}{*}{$\begin{array}{l}\text { 乾燥 } \\
\text { ケーキ }\end{array}$} & \multirow{2}{*}{$\begin{array}{l}\text { 熱分解 } \\
\text { 残㵓 }\end{array}$} & \multicolumn{2}{|c|}{ 液体成分 } & \multirow{2}{*}{$\begin{array}{l}\text { 生成 } \\
\text { ガス }\end{array}$} & \multirow{2}{*}{ 分析方法·装置 } \\
\hline & & & 水分 & タール分 & & \\
\hline 含水率 & O & O & \multicolumn{2}{|c|}{ O } & & 下水試験方法2.4.6に二準拠 \\
\hline 灰分 & O & O & & O & & 下水試験方法2.4.81準拠するが, $900^{\circ} \mathrm{C} て ゙$ 加熱 \\
\hline CHN組成 & O & O & & O & & CHNコーダ(MT-2: 柳本製作所製) \\
\hline 発熱量 & O & O & & O & & $\begin{array}{c}\text { ボンブ断熱熱量計 } \\
\text { (OSK150: 小川ハブリン゙製) }\end{array}$ \\
\hline 生成ガス成分測定 & & & & & O & $\begin{array}{c}\mathrm{CO}_{2}, \text { 炭化水素:マイクロガスクロマトグラフ } \\
\text { (マイクロGC CP-2000:クロムパック製) } \\
\text { H } 2 \text {, CO: ガスクロマトグラフ } \\
\text { (HP-5890A: Hewlett Packard製) }\end{array}$ \\
\hline
\end{tabular}


$H_{U}$ : 低位発熱量 $(\mathrm{MJ} / \mathrm{kg})$,

$H_{O}:$ 高位発熱量 $(\mathrm{MJ} / \mathrm{kg})$,

$h:$ 水素の含有割合 $(\%), w$ : 含水率 $(\%)$.

\section{b) 液体成分}

実験終了後に，図-1における石英管内に巻きつけ たガラス繊維ろ紙(i) および 1 番目のフラスコ内のガ ラス繊維ろ紙(ii) を用いて配管内の付着成分をできる だけふき取って回収し，その重量を測定した。液 体成分をふき取ったこれらのガラス繊維ろ紙は, 水分除去のためシリカゲル入りデシケータで約 $96 \mathrm{hr}$ 乾燥させた後その重量を測定した。以下では デシケータによる乾燥によって揮発した成分を 「水分」, 乾燥後ガラス繊維ろ紙中に残存した成分 を「タール分」と呼んで区別することとする。

水分, タール分発生量は式(2), (3) で定義した.

$$
\begin{gathered}
M_{T}=\left(\Delta M_{L}-\Delta M_{L U}\right) \times \frac{W_{\text {GFdry }}-W_{\text {GFbefore }}}{W_{\text {GFafter }}-W_{\text {GFbefore }}} \\
M_{W}=\Delta M_{L}-M_{T}
\end{gathered}
$$

$M_{T}$ : タール分重量 $(\mathrm{mg}), M_{W}$ : 水分重量 $(\mathrm{mg})$, $\Delta M_{L}$ : トラップされた液体成分総重量 $(\mathrm{mg})$,

$\Delta M_{L U}$ : U字管でトラップされた液体成分重量 $(\mathrm{mg})$, $W_{G F d r y}$ : デシケータで乾燥後のろ紙重量 $(\mathrm{mg})$,

$W_{\text {GFafter }}$ : 実験後のろ紙重量 $(\mathrm{mg})$,

$W_{\text {GFbefore }}$ : 実験前のろ紙重量 $(\mathrm{mg})$.

乾燥後のガラス繊維ろ紙は，乾燥ケーキ，およ び熱分解残渣と同様の方法で, タール分の灰分, CHN 組成，および高位発熱量を測定し，低位発熱 量を算出した。また, 液体成分としての低位発熱 量の算出には, 水分量と, タール分の低位発熱量 から算出した。

\section{c) 生成ガス}

生成ガスに関しては，テドラーバッグに捕集さ れたガスについて成分測定を行った。成分は， $\mathrm{H}_{2}$, $\mathrm{CO}, \mathrm{CO}_{2}, \mathrm{CH}_{4}, \mathrm{C}_{2} \mathrm{H}_{4}, \mathrm{C}_{2} \mathrm{H}_{6}, \mathrm{C}_{3} \mathrm{H}_{6}, \mathrm{C}_{3} \mathrm{H}_{8}, 1-\mathrm{C}_{4} \mathrm{H}_{8}, \mathrm{n}-$ $\mathrm{C}_{4} \mathrm{H}_{10}$ の 10 種類とした. これらの測定には, $\mathrm{CO}_{2}$ と 炭化水素 7 種類はマイクロガスクロマトグラフ $(\mathrm{CP}-$ 2000 : クロムパック製) を用い, $\mathrm{H}_{2}$ と CO はガスク ロマトグラフ (HP-5890A : Hewlett Packard製)を用い た。これらの機器による分析条件をそれぞれ表 -2 , 表-3に示した.

以上の熱分解実験の一連のフローを図-2 に示し た.

\begin{tabular}{|c|c|c|c|}
\hline \multicolumn{2}{|c|}{ チャンネル } & Chan.A & Chan.B \\
\hline \multicolumn{2}{|c|}{ 測定対象 } & $\begin{array}{l}\mathrm{CO}_{2}, \mathrm{CH}_{4}, \mathrm{C}_{2} \mathrm{H}_{4} \\
\mathrm{C}_{2} \mathrm{H}_{6}, \mathrm{C}_{3} \mathrm{H}_{6}, \mathrm{C}_{3} \mathrm{H}_{8}\end{array}$ & $1-\mathrm{C}_{4} \mathrm{H}_{8}, \mathrm{n}-\mathrm{C}_{4} \mathrm{H}_{10}$ \\
\hline \multicolumn{2}{|c|}{ 装置 } & \multicolumn{2}{|c|}{ " CP-2000 (クロムパック製) } \\
\hline \multicolumn{2}{|c|}{ キャリアガス } & \multicolumn{2}{|c|}{$\mathrm{He}$} \\
\hline \multirow{3}{*}{ カラム } & 名称 & PolaplotQ & CP-Sil 5CB \\
\hline & 長さ×内径 & $0.25 \mathrm{~m}$ & $0.25 \mathrm{~m}$ \\
\hline & 温度 & $60^{\circ} \mathrm{C}$ & $40^{\circ} \mathrm{C}$ \\
\hline \multicolumn{2}{|c|}{ キャリアガス圧カ } & $80 \mathrm{kPa}$ & $80 \mathrm{kPa}$ \\
\hline \multicolumn{2}{|c|}{ 注入時間 } & \multicolumn{2}{|c|}{$100 \mathrm{msec}$} \\
\hline \multicolumn{2}{|c|}{ 分析時間 } & \multicolumn{2}{|c|}{$150 \mathrm{sec}$} \\
\hline \multirow{2}{*}{ 検出器 } & 種類 & \multicolumn{2}{|c|}{ 熱伝導度検出器(TCD) } \\
\hline & 感度 & $\operatorname{Mid}(※)$ & $\operatorname{Mid}(※)$ \\
\hline
\end{tabular}

表-2 マイクロ GC 測定条件

\begin{tabular}{|c|c|c|c|}
\hline \multicolumn{2}{|c|}{ 測定対象 } & $\mathrm{CO}$ & $\mathrm{H}_{2}$ \\
\hline \multicolumn{2}{|c|}{ 装置 } & \multicolumn{2}{|c|}{$\begin{array}{c}\text { HP-5890A } \\
\text { (Hewlett Packard製) }\end{array}$} \\
\hline \multicolumn{2}{|c|}{ 注入口温度 } & \multicolumn{2}{|c|}{$100^{\circ} \mathrm{C}$} \\
\hline \multirow{4}{*}{ カラム } & 名称 & \multicolumn{2}{|c|}{ HP-Plot Molecular Sieve 5A } \\
\hline & 長さ×内径 & \multicolumn{2}{|c|}{$30 \mathrm{~m} \times 0.53 \mathrm{~mm}$} \\
\hline & 膜厚 & \multicolumn{2}{|c|}{$50.0 \mu \mathrm{m}$} \\
\hline & 温度 & $60^{\circ} \mathrm{C}$ & $50^{\circ} \mathrm{C}$ \\
\hline \multirow{2}{*}{ 検出器 } & 種類 & \multicolumn{2}{|c|}{ 熱伝導度検出器(TCD) } \\
\hline & 温度 & \multicolumn{2}{|c|}{$200^{\circ} \mathrm{C}$} \\
\hline \multirow{2}{*}{ キャリアガス } & 種類 & $\mathrm{He}$ & $\mathrm{N}_{2}$ \\
\hline & 流量 & $15 \mathrm{~mL} / \mathrm{min}$ & $6.0 \mathrm{~mL} / \mathrm{min}$ \\
\hline \multicolumn{2}{|c|}{ スプリット比 } & $1: 6$ & $1: 1.5$ \\
\hline \multicolumn{2}{|c|}{ 注入量 } & $200 \mu \mathrm{L}$ & $500 \mu \mathrm{L}$ \\
\hline
\end{tabular}

表-3 GC 測定条件

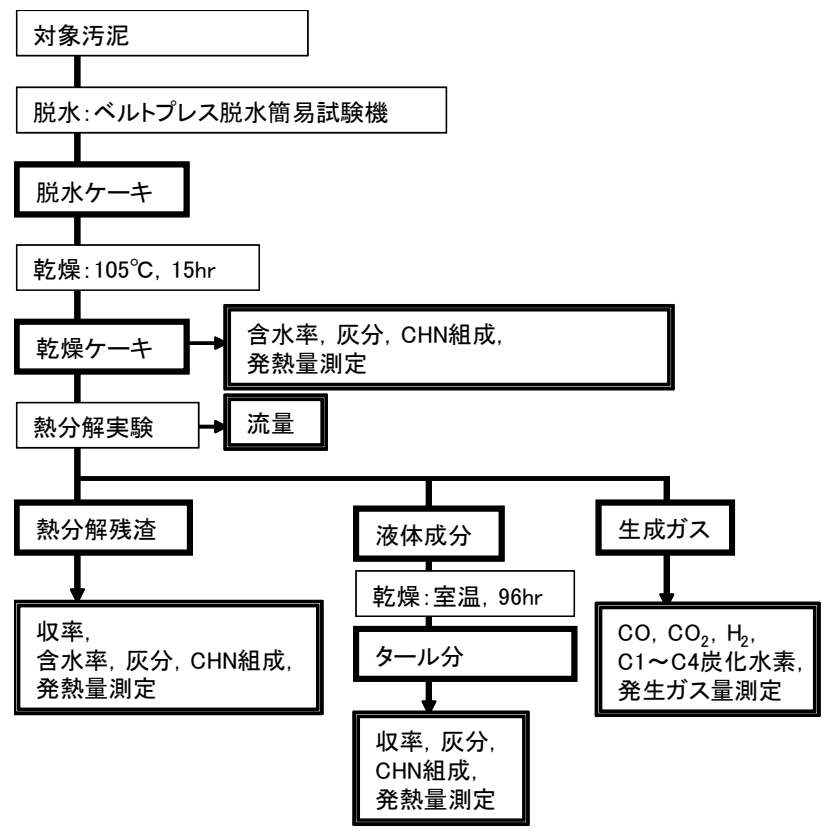

図-2＼cjkstart実験の概要フロー 


\section{3. 実験結果および考察}

\section{（1）供試污泥の性状}

熱分解実験に供した乾燥ケーキの組成を表 -4に 示した，性状としては，含水率が $2.4 \%$ であり，炭 素 $35.4 \%$, 水素 $7.2 \%$, 窒素 $5.5 \%$ を含み，その他の主 要な元素としては $\mathrm{Al}, \mathrm{Ca}, \mathrm{Fe}, \mathrm{P}$ を $1.2 〜 2.0 \%$ 程度 含んでいた。高位発熱量は $16.6 \mathrm{MJ} / \mathrm{kg}$, 低位発熱量 は $15.0 \mathrm{MJ} / \mathrm{kg}$ であり, 高位発熱量に関してはやや低 いが，污泥乾燥ケーキとしての標準的な範囲とさ れる $15 \sim 19 \mathrm{MJ} / \mathrm{kg}$ の範囲にあった ${ }^{7)}$.

\section{(2) 各成分の収率}

熱分解温度と熱分解残渣，液体成分 (水分，およ びタール分), 生成ガスの収率をそれぞれの温度域 での平均值として図-3に示した。 それぞれの収率 は式(4)〜 (8) で定義した。

$$
\begin{gathered}
y_{R}=\left(M_{R} / M_{D S}\right) \times 100 \\
y_{L}=\left(\Delta M_{L} / M_{D S}\right) \times 100 \\
y_{W}=\left(M_{W} / M_{D S}\right) \times 100 \\
y_{T}=\left(M_{T} / M_{D S}\right) \times 100 \\
y_{G}=\left(\sum_{i=1}^{10} M_{G i} / M_{D S}\right) \times 100
\end{gathered}
$$

\begin{tabular}{|c|c|c|c|}
\hline 評価項目 & 単位 & 值 & 分析機器 \\
\hline 含水率 & $\%$ & 2.4 & - \\
\hline 灰分 & $\%-T S$ & 26.5 & - \\
\hline C & $\%-T S$ & 35.4 & CHNコーダ \\
\hline $\mathrm{H}$ & $\%$-TS & 7.19 & CHNコーダ \\
\hline $\mathrm{N}$ & $\%$-TS & 5.53 & 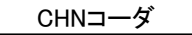 \\
\hline $\mathrm{Al}$ & $\mathrm{mg} / \mathrm{kg}-\mathrm{TS}$ & 17800 & ICP-AES \\
\hline $\mathrm{Ca}$ & $\mathrm{mg} / \mathrm{kg}-\mathrm{TS}$ & 12500 & ICP-AES \\
\hline Cd & $\mathrm{mg} / \mathrm{kg}-\mathrm{TS}$ & 1.51 & ICP-AES \\
\hline Co & $\mathrm{mg} / \mathrm{kg}-\mathrm{TS}$ & 17.0 & ICP-AES \\
\hline $\mathrm{Cr}$ & $\mathrm{mg} / \mathrm{kg}-\mathrm{TS}$ & 199 & ICP-AES \\
\hline $\mathrm{Cu}$ & $\mathrm{mg} / \mathrm{kg}-\mathrm{TS}$ & 779 & ICP-AES \\
\hline $\mathrm{Fe}$ & $\mathrm{mg} / \mathrm{kg}-\mathrm{TS}$ & 19500 & ICP-AES \\
\hline K & $\mathrm{mg} / \mathrm{kg}-\mathrm{TS}$ & 171 & ICP-AES \\
\hline $\mathrm{Mg}$ & $\mathrm{mg} / \mathrm{kg}-\mathrm{TS}$ & 2890 & ICP-AES \\
\hline $\mathrm{Mn}$ & $\mathrm{mg} / \mathrm{kg}-\mathrm{TS}$ & 1680 & ICP-AES \\
\hline $\mathrm{Ni}$ & $\mathrm{mg} / \mathrm{kg}-\mathrm{TS}$ & 94.8 & ICP-AES \\
\hline $\mathrm{P}$ & $\mathrm{mg} / \mathrm{kg}-\mathrm{TS}$ & 15700 & ICP-AES \\
\hline $\mathrm{Pb}$ & $\mathrm{mg} / \mathrm{kg}-\mathrm{TS}$ & 27.1 & ICP-AES \\
\hline $\mathrm{Zn}$ & $\mathrm{mg} / \mathrm{kg}-\mathrm{TS}$ & 2630 & ICP-AES \\
\hline 高位発熱量 & $\mathrm{MJ} / \mathrm{kg}$ & 16.6 & ボンブ熱量計 \\
\hline 低位発熱量 & $\mathrm{MJ} / \mathrm{kg}$ & 15.0 & 高位発熱量からの計算値 \\
\hline
\end{tabular}

$y_{R}$ : 熱分解残渣収率 $(\%), y_{L}$ : 液体成分収率 $(\%)$, $y_{T}$ : タール分の収率 $(\%), y_{W}$ : 水分の収率 $(\%)$, $y_{G}:$ 生成ガス収率 $(\%)$,

表-4 乾燥ケーキの組成分析結果
$M_{D S}:$ 乾燥ケーキ固形分重量 +吹込水蒸気量 $(\mathrm{mg})$, $M_{R}:$ 熱分解残渣重量 $(\mathrm{mg})$,

$\Delta M_{L}$ : トラップされた液体成分の総重量 $(\mathrm{mg})$,

$M_{T}$ : タール分重量 $(\mathrm{mg}), M_{W}$ : 水分重量 $(\mathrm{mg})$,

$M_{G i}:$ 各ガス生成量 $(\mathrm{mg})$.

図-3より, 熱分解残渣の収率は熱分解温度の上 昇とともに減少したが, $300 \sim 500^{\circ} \mathrm{C}$ での収率の減 少が約 30\% であるのに対し， $500 \sim 700^{\circ} \mathrm{C}$ ，および $700 \sim 900^{\circ} \mathrm{C}$ での収率の減少は, $4 \sim 6 \%$ 程度であっ た. $900^{\circ} \mathrm{C}+$ 水蒸気の条件では, $900^{\circ} \mathrm{C} の$ 条件からさ らに $16 \%$ 程度減少していた。次に, 水分の収率は $300 \sim 500^{\circ} \mathrm{C}$ の範囲では, $8 \%$ 程度増加し, $500^{\circ} \mathrm{C}$ 以上 では $\pm 3 \%$ 以内の差でほぼ一定であった. $900^{\circ} \mathrm{C}+$ 水 蒸気の条件では $5 \%$ 程度上昇した. タール分の収率 は $500^{\circ} \mathrm{C}$ で最大の $21 \%$ となったが, $500^{\circ} \mathrm{C}$ 以上では, 温度上昇にともなって減少し， $900^{\circ} \mathrm{C}$ で約 $6.9 \%$ で あった。 さらに, $900^{\circ} \mathrm{C}+$ 水蒸気の条件では, $2.8 \%$ まで減少した。生成ガスの収率は, 熱分解温度の 上昇とともに直線的に増加し, $900{ }^{\circ} \mathrm{C}$ では $15 \%$ 程度 であり, $900^{\circ} \mathrm{C}+$ 水蒸気の条件で最大の $25 \%$ であっ た。

一般的に, 有機物の熱分解は, $200^{\circ} \mathrm{C}$ までに水分 の蒸発による乾燥が生じ, $200 \sim 500^{\circ} \mathrm{C}$ では有機性 成分の乾留によるメタンなどのガス生成と, ター ル分などの液体成分の生成が生じる。液体成分の うち凝縮水は $300^{\circ} \mathrm{C}$ までは増加するが, 温度が上が ると一定となる.さらに, $500^{\circ} \mathrm{C} \sim 1200^{\circ} \mathrm{C}$ では, ター ル分の低分子化, およびガス化, 固定炭素のガス 化が生じるとされる ${ }^{8), 9)}$. さらに水蒸気が存在する と, 式(9)〜(11)に示すような水性ガス反応(式(9)), シフト反応 (式(11)) に代表されるガス改質がなさ れ, 結果として熱分解残渣の収率が減少し, 生成 ガス収率が増加するとされる ${ }^{9}$.

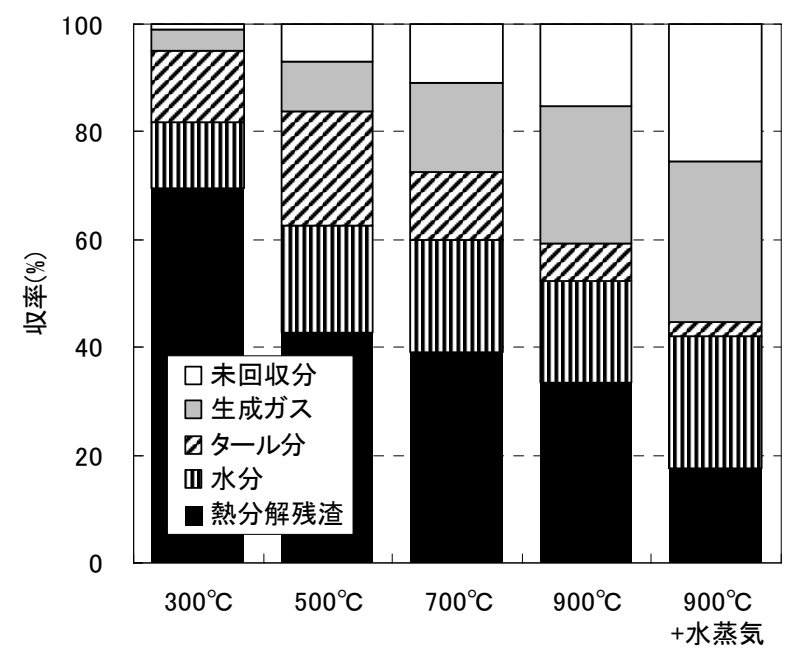

図-3 各実験条件における収率 


$$
\begin{gathered}
\mathrm{C}+\mathrm{H}_{2} \mathrm{O} \rightarrow \mathrm{CO}+\mathrm{H}_{2} \\
\mathrm{C}+2 \mathrm{H}_{2} \mathrm{O} \rightarrow \mathrm{CO}_{2}+2 \mathrm{H}_{2} \\
\mathrm{CO}+\mathrm{H}_{2} \mathrm{O} \rightarrow \mathrm{CO}_{2}+\mathrm{H}_{2}
\end{gathered}
$$

図-3に示した熱分解温度をはじめとする各条件 と 4 成分の収率の関係は，主に以下の 5 つの点で上 記のことを裏付けている.

I. $300 \sim 500^{\circ} \mathrm{C}$ における熱分解残渣収率の大 きな減少.

II. $300 \sim 500^{\circ} \mathrm{C}$ におけるタール分収率の増加 と 500 度以上における減少.

III. $500^{\circ} \mathrm{C}$ 以上での水分収率がほぼ一定.

IV. 温度上昇に伴う生成ガス収率の増大.

$\mathrm{V} .900^{\circ} \mathrm{C}$ での水蒸気添加による熱分解残渣収 率の増大と生成ガス収率の増大.

さらに, 図-3 の傾向は, 熱分解温度の報告值に 若干の違いはあるが文献 10), 11) と同様の傾向であつ たことから，本実験系で下水污泥を対象とした熱 分解を実現できていると判断した。

上記成分の収率の合計としては，3000 C では $96.7 \%, 500^{\circ} \mathrm{C}$ で $90.7 \%, 700^{\circ} \mathrm{C}$ で $88.4 \%$, および $900^{\circ} \mathrm{C}$ で $82.9 \%, 900^{\circ} \mathrm{C}+$ 水蒸気で $75 \%$ であり，熱分解温度 が上昇するにつれて未回収分が増加した。未回収

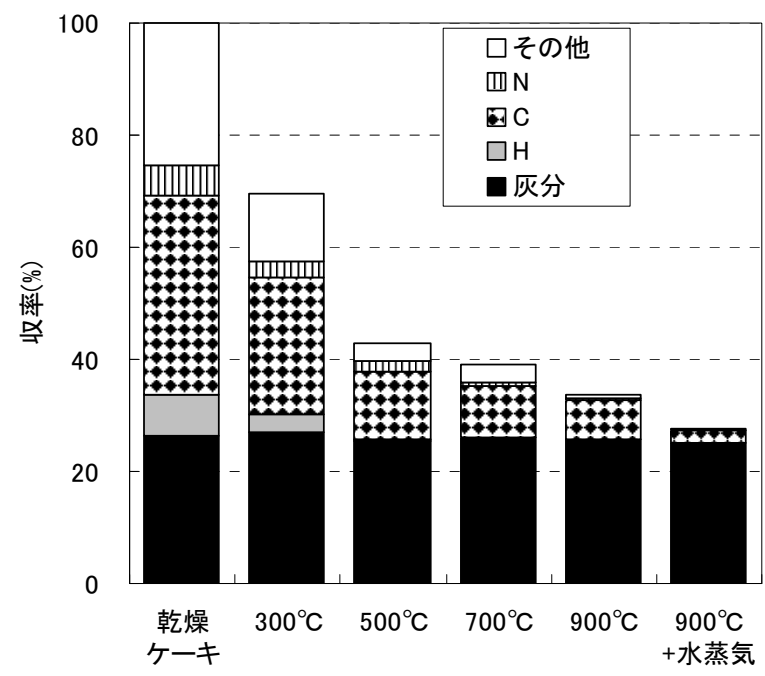

図-4 熱分解残渣の組成変化
分には熱分解残渣よりも移動性の高い液体成分と 生成ガスの $2 つ の$ 寄与が考えられる. 液体成分由来 の未回収分は, 特に $700^{\circ} \mathrm{C}, 900^{\circ} \mathrm{C}$ の場合, 熱分解生 成物が比較的高温を保った状態で，かつ高い流速 でトラップを通過するため, 液体成分が凝縮しき らなかったことによると考えられる。また，生成 ガス由来の未回収分は, 測定対象としなかった, $\mathrm{N}_{2}, \mathrm{NH}_{3}, \mathrm{H}_{2} \mathrm{~S}$, および $\mathrm{HCl}$ などの $\mathrm{S}, \mathrm{N}, \mathrm{Cl}$ を含む 成分によると考えられる。

\section{（3）熱分解残渣の性状 \\ a) $\mathrm{CHN}$ 組成}

乾燥ケーキと得られた熱分解残渣の組成を灰分, 炭素, 窒素, 水素, その他の5つに分画して乾燥ケー キ固形分重量に対する組成割合を熱分解温度条件 毎の平均值として図-4 に示した. その他の成分と しては主に $\mathrm{O}$ の他， $\mathrm{S} ， \mathrm{Cl}$ 分などが考えられる．炭 素は熱分解温度の上昇に伴って, 割合は減少した が, $500^{\circ} \mathrm{C}$ まで減少割合が最も大きく, $700^{\circ} \mathrm{C}$ 以上 では減少割合は低くなった，ただし，900 $\mathrm{C}+$ 水蒸 気の条件では $900^{\circ} \mathrm{C}$ に比較して $5 \%$ 程度炭素割合が 減少しており, 式(9)の水性ガス反応や, それに付 随する式(10)の反応が生じていると考えられる.酸 素に代表されるその他の成分に関しても，炭素と ほぼ同様の傾向を示した。窒素に関しても，熱分 解温度の上昇に伴って，割合は減少したが，炭素 とは逆に $500^{\circ} \mathrm{C}$ 以上での減少割合が大きくなった。 $500^{\circ} \mathrm{C}$ 付近では, 污泥中の窒素化合物からのアンモ ニアの発生が最も多くなるとされており ${ }^{8)}$, 上記の 結果は, 污泥から生成ガスに窒素分が移行したこ とによると考えられる。また, 図-4より, 窒素, 水 素やその他の成分は $700^{\circ} \mathrm{C}$ 以上ではほとんど熱分解 残渣中に残留しなかった。

\section{b) 発熱量}

熱分解残渣単位重量あたりの高位発熱量の測定 結果の平均值および低位発熱量の計算結果を表 -5

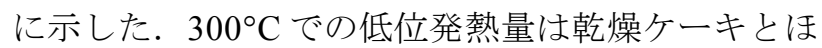
ぼ同程度であり，約 $15 \mathrm{MJ} / \mathrm{kg}$ であった。これは，

表-5 熱分解残渣の発熱量と回収熱量

\begin{tabular}{l|rrrrrr}
\hline & $\begin{array}{c}\text { 乾燥 } \\
\text { ケーキ }\end{array}$ & $300^{\circ} \mathrm{C}$ & $500^{\circ} \mathrm{C}$ & $700^{\circ} \mathrm{C}$ & $900^{\circ} \mathrm{C}$ & $\begin{array}{c}900^{\circ} \mathrm{C} \\
\text { +水蒸気 }\end{array}$ \\
\hline \hline $\begin{array}{l}\text { 高位発熱量 } \\
(\mathrm{MJ} / \mathrm{kg})\end{array}$ & 16.6 & 16.3 & 11.3 & 9.84 & 9.14 & 1.39 \\
\hline $\begin{array}{l}\text { 低位発熱量 } \\
(\mathrm{MJ} / \mathrm{kg})\end{array}$ & 15.0 & 15.2 & 11.3 & 9.82 & 9.12 & 1.39 \\
\hline $\begin{array}{l}\text { 回収熱量 } \\
(\mathrm{MJ} / \mathrm{kg} \text {-乾燥ケーキ) }\end{array}$ & 15.0 & 10.6 & 4.84 & 3.83 & 3.06 & 0.36 \\
\hline
\end{tabular}


$300^{\circ} \mathrm{C}$ 程度までの温度領域では，それまでに揮発す る成分の脱酸素作用によって, 発熱量の高い成分 の残存割合が高くなることによるものとされる ${ }^{3)}$. $500^{\circ} \mathrm{C}$ 以上では，熱分解温度が高くなるにつれて発 熱量は減少したが, 減少割合は高温になるにつれ て小さくなる傾向を示した。ただし， $900^{\circ} \mathrm{C}+$ 水蒸 気の条件では, 図-4に示したように, 熱分解残渣 中の炭素の割合が低下し，ほとんどが灰分となる ため発熱量は極端に減少し, 低位発熱量は $1.39 \mathrm{MJ} /$ $\mathrm{kg}$ であった。

図-3に示したように, 熱分解温度の上昇に伴っ て熱分解残渣収率も減少するため，表 -5 に回収熱 量として, 乾燥ケーキ単位重量あたりの熱分解残 渣の低位発熱量を示した。表より， $300^{\circ} \mathrm{C}$ では熱分 解残渣として回収できる熱量は $10.6 \mathrm{MJ} / \mathrm{kg}$ - 乾燥ケー キであり，乾燥ケーキ低位発熱量の約 $70 \%$ の回収 が期待できる. $500^{\circ} \mathrm{C}$ 以上では熱分解残渣収率と単 位重量あたりの低位発熱量がともに減少するため 相乗効果により大幅に減少し， $500^{\circ} \mathrm{C}$ では約 $30 \%$, $900^{\circ} \mathrm{C}$ では約 $20 \%, 900^{\circ} \mathrm{C}+$ 水蒸気では約 $2.5 \%$ 程度と なった。この観点からは熱分解残渣を燃料利用す る際には， $500^{\circ} \mathrm{C}$ 以上の熱分解では，污泥の有する 本来の熱量を残渣側に十分に残せないため, $300^{\circ} \mathrm{C}$ に比較して不利であるといえる。

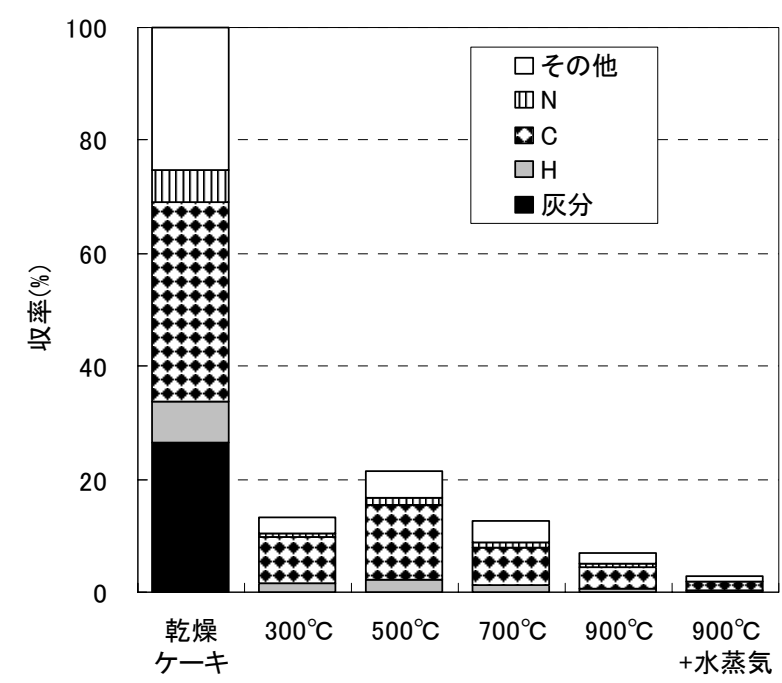

図-5 タール分の組成変化

\section{（4）タール分の性状}

\section{a) $\mathbf{C H N}$ 組成}

乾燥ケーキと得られたタール分の組成を扊分, 炭素, 窒素, 水素, その他の5つに分画して乾燥ケー キ固形分重量に対する組成割合の平均值を熱分解 温度条件毎に図-5に示した. タール分としての組 成割合としては全ての温度条件で，炭素が50 60\%, 窒素が $5 \sim 6 \%$, 水素が $9 \sim 11 \%$ 程度であり, 熱分解温度による明確な影響はみられなかった。 また図 -5 はタール分の収率を反映しているが，炭 素, 窒素, 水素の物質移動としては, 乾燥ヶーキ の炭素の約 4〜40\%, 水素の $4 \sim 30 \%$, 窒素の $2.5 \sim$ $20 \%$ がタール分に移行した。

\section{b) 発熱量}

タール分の単位重量あたりの高位発熱量測定結 果の平均值, および低位発熱量の計算結果を表 -6 に示した. タール分低位発熱量は28.3〜 $31.8 \mathrm{MJ} / \mathrm{kg}$ であり，乾燥ケーキの低位発熱量の 2 倍程度であっ た。これは，タール分には扊分がほとんどなく，炭 素の割合が半分以上を占めていることによるもの と考えられる。また, タール分に水分を加えた液 体成分としての低位発熱量は, 熱分解温度の上昇 とともに $14.9 \mathrm{MJ} / \mathrm{kg}$ から $6.7 \mathrm{MJ} / \mathrm{kg}$ まで減少し, $900^{\circ} \mathrm{C}$ + 水蒸気の条件では $1.06 \mathrm{MJ} / \mathrm{kg}$ まで減少する傾向を 示したが，これは液体成分中のタール分の割合が 減少し，水分の割合が増加することによる。

図-3に示したように, 熱分解温度の上昇に伴っ て水分, タール分の収率も変動するため, 表 -6 に 回収熱量として, 乾燥ケーキ単位重量あたりの液 体成分の低位発熱量を示した。液体成分としての 回収熱量は $0.29 \sim 5.7 \mathrm{MJ} / \mathrm{kg}$ - 乾燥ケーキであり, 乾

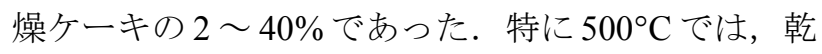
燥厅ーキの $40 \%$ が液体成分に移行した。

このように，タール分が多く生成してしまうと， 結果として，実機においてもトラブルの原因とな り得る他, 熱分解残渣や, 生成ガスに移行する熱 量が減少する要因となる. タール分の対策には，生 成したタールの触媒などによる改質4)や, 下水污泥 以外の木質バイオマスにおいて, 発生抑制のため

表-6 タール分および液体成分の発熱量と回収熱量

\begin{tabular}{|c|c|c|c|c|c|c|}
\hline & $\begin{array}{l}\text { 乾燥 } \\
\text { ケーキ }\end{array}$ & $300^{\circ} \mathrm{C}$ & $500^{\circ} \mathrm{C}$ & $700^{\circ} \mathrm{C}$ & $900^{\circ} \mathrm{C}$ & $\begin{aligned} & 900^{\circ} \mathrm{C} \\
+ & \text { 水蒸気 }\end{aligned}$ \\
\hline $\begin{array}{l}\text { 高位発熱量 } \\
(\mathrm{MJ} / \mathrm{kg})\end{array}$ & 16.6 & 33.8 & 31.4 & 30.6 & 33.9 & 34.1 \\
\hline $\begin{array}{l}\text { 低位發熱量 } \\
(\mathrm{MJ} / \mathrm{kg})\end{array}$ & 15.0 & $31.2(14.9)$ & $29.0(13.9)$ & $28.3(9.18)$ & $31.7(6.73)$ & $31.8(1.06)$ \\
\hline $\begin{array}{l}\text { 回収熱量 } \\
\text { (MJ/kg-乾燥ケーキ) }\end{array}$ & 15.0 & (3.83) & (5.71) & (3.09) & (1.72) & (0.42) \\
\hline
\end{tabular}



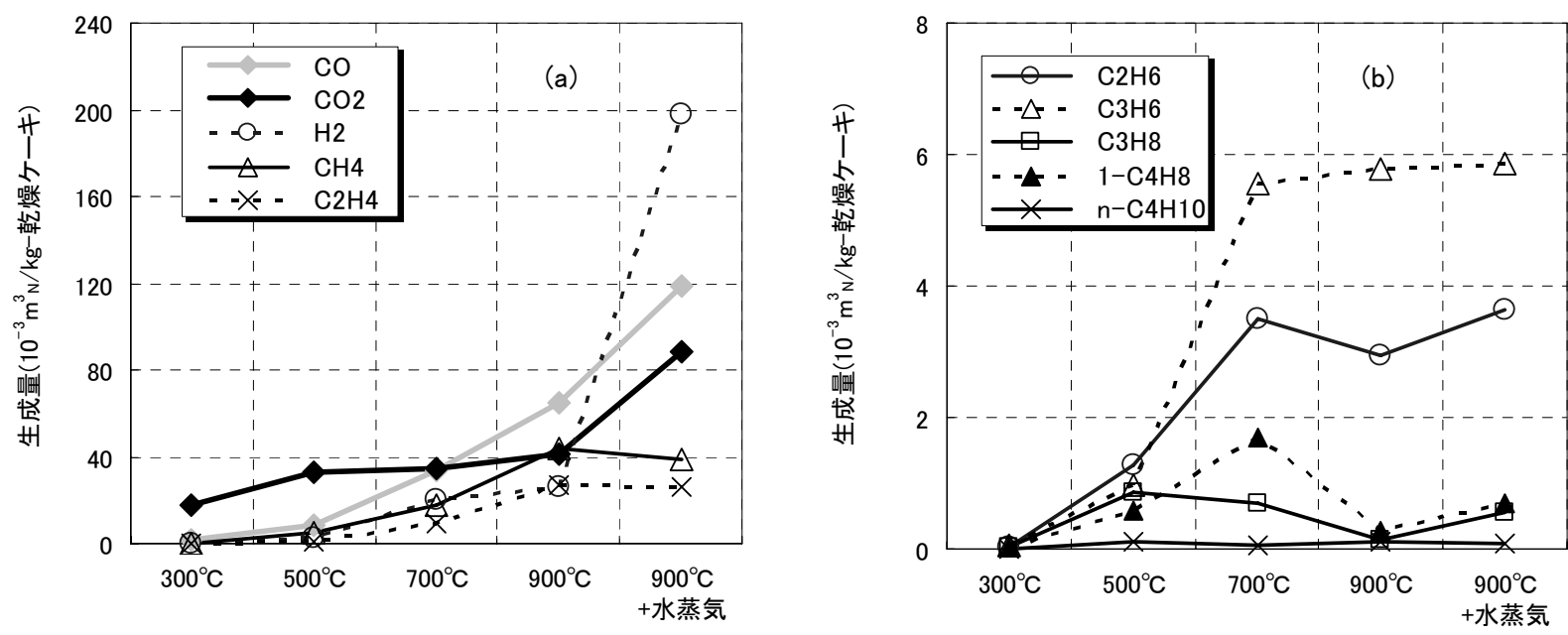

図-6 各実験条件におけるガス生成量

(a): $\mathrm{H}_{2}, \mathrm{CO}, \mathrm{CO}_{2}, \mathrm{CH}_{4}, \mathrm{C}_{2} \mathrm{H}_{4}$, (b): $\mathrm{C}_{2} \mathrm{H}_{6}, \mathrm{C}_{3} \mathrm{H}_{6}, \mathrm{C}_{3} \mathrm{H}_{8}, 1-\mathrm{C}_{4} \mathrm{H}_{8}, \mathrm{n}_{-} \mathrm{C}_{4} \mathrm{H}_{10}$

の装置構造が検討されているが12), 本研究の結果 からは，発生抑制のために低温域での熱分解，あ るいは生成してもガス化できるような高温域での 熱分解が重要であるといえる.

\section{（5）生成ガス成分の性状}

\section{a) ガス組成}

測定対象とした 10 種類のガス成分の生成量の平 均值について, 乾燥ケーキ単位重量あたりから生 成する体積に換算して，図-6に示した。

まず $\mathrm{CO}, \mathrm{CO}_{2}, \mathrm{H}_{2}$ に関しては, 熱分解温度の上 昇とともに生成量が増加する傾向がみられた。特 に $\mathrm{H}_{2}$ は, $700^{\circ} \mathrm{C}$ 以上で増加する傾向を示し, $900^{\circ} \mathrm{C}+$ 水蒸気の条件では最大 $200 \times 10^{-3} \mathrm{~m}^{3}{ }_{\mathrm{N}} / \mathrm{kg}$ - 乾燥ケーキま で増加した。これは, 式 (9)〜 (11) のガス改質反応 が生じているものと考えられる。COに関しては, $700^{\circ} \mathrm{C}$ ま゙は $\mathrm{CO}<\mathrm{CO}_{2}$ であったが $900^{\circ} \mathrm{C}, 900^{\circ} \mathrm{C}+$ 水蒸 気では $\mathrm{CO}>\mathrm{CO}_{2}$ と逆転した。 この現象は, 余剰污泥 の熱分解を調査した研究 ${ }^{11)}$ においても同様の傾向 が報告されているが， $700^{\circ} \mathrm{C}$ 以上になると，温度が 上昇するにしたがって，式(12)の Boudouard 反応の 平衡が温度条件によって変化し CO 濃度が増加する ことによる ${ }^{9)}$ 上に, 式 $(9) \sim(11)$ のガス改質反応も 加わり, これらの平衡関係により, 結果として CO 濃度が増加するものと考えられる。

$$
\mathrm{CO}_{2}+\mathrm{C} \leftrightarrow 2 \mathrm{CO}
$$

また炭化水素としては $\mathrm{CH}_{4}$ や，不飽和炭化水素の $\mathrm{C}_{2} \mathrm{H}_{4}, \mathrm{C}_{3} \mathrm{H}_{6}$ が比較的多く生成し, 熱分解温度の上昇 とともに生成量が増加する傾向がみられた。あま

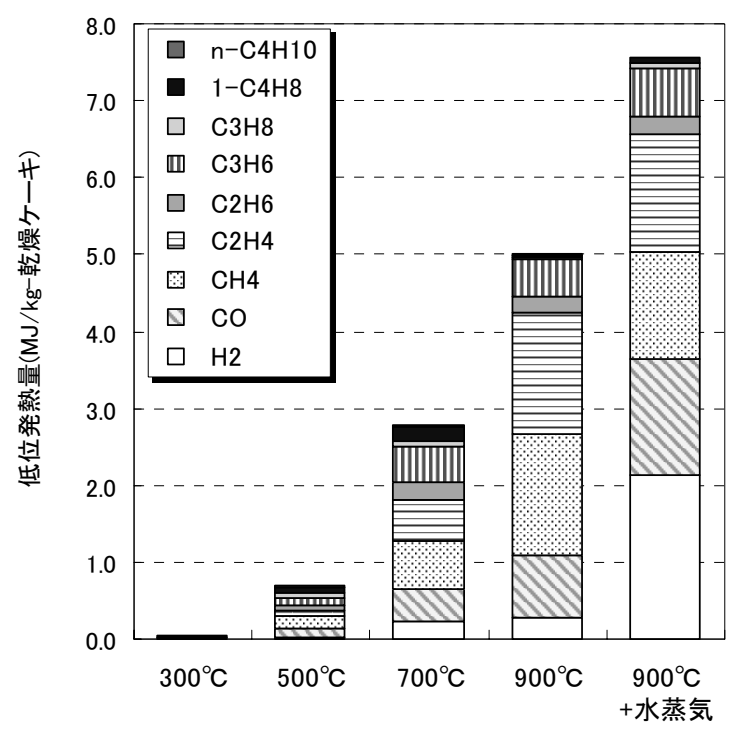

図-7 各実験条件における生成ガス低位発熱量

り発生量の多くなかった $\mathrm{C}_{2} \mathrm{H}_{6}, \mathrm{C}_{3} \mathrm{H}_{8}$ などの飽和炭 化水素類については，その生成量が $700^{\circ} \mathrm{C}$ 以上では 一旦頭打ちあるいは減少する傾向をみせた。この 現象は，550〜 $650^{\circ} \mathrm{C}$ 以上になると, $\mathrm{C}_{2} \mathrm{H}_{6}$ などのア ルカンは熱分解し $\mathrm{CH}_{4}, \mathrm{C}_{2} \mathrm{H}_{4}, \mathrm{C}_{4} \mathrm{H}_{10}$ を生成する反応 が生じると報告されている ${ }^{13)} \cdot \mathrm{C}_{4} \mathrm{H}_{10}$ に関しては, n$\mathrm{C}_{4} \mathrm{H}_{10}$ のみの測定でありはっきりしないが，少なく とも $\mathrm{CH}_{4}, \mathrm{C}_{2} \mathrm{H}_{4}$ に関してはこの温度範囲で顕著に増 加していることから， $\mathrm{C}_{2} \mathrm{H}_{6}, \mathrm{C}_{3} \mathrm{H}_{8}$ の熱分解が生じて いると考えられる.

\section{b) 発熱量}

図-6における結果を元に，乾燥ケーキ $1 \mathrm{~kg}$ から 得られる生成ガスの低位発熱量を算出し, 図-7に 示した。温度の上昇に伴い低位発熱量は大きく増 加し, $300^{\circ} \mathrm{C}$ では $0.038 \mathrm{MJ} / \mathrm{kg}$ - 乾燥ケーキであったも 
のが $900^{\circ} \mathrm{C}+$ 水蒸気では $7.57 \mathrm{MJ} / \mathrm{kg}$ - 乾燥ケーキとな り，約 200 倍の值を示した。成分ごとの寄与として は, $\mathrm{CO}, \mathrm{H}_{2}, \mathrm{CH}_{4}, \mathrm{C}_{2} \mathrm{H}_{4}$ の寄与が大きかったが，温 度との関係では, 温度が上昇するにつれ $\mathrm{H}_{2}$ や炭化 水素類の寄与が大きくなり, 炭化水素類は, $500^{\circ} \mathrm{C}$ 〜 $900^{\circ} \mathrm{C}$ では全体の約 $80 \%$ を占めていたが， $900^{\circ} \mathrm{C}+$ 水蒸気では, 式(9)〜 (11) に示されるガス改質反応 により, $\mathrm{CO}, \mathrm{H}_{2}$ の生成量が増加し, 炭化水素 : $\mathrm{CO}$ $+\mathrm{H}_{2}$ の比率は $1: 1$ 程度となった。

元々の乾燥ケーキの低位発熱量は $15 \mathrm{MJ} / \mathrm{kg}$ - 乾燥

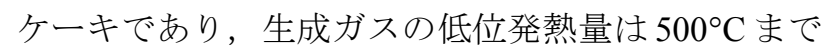
は乾燥ケーキ低位発熱量の $5 \%$ 以下であったが, $700^{\circ} \mathrm{C}$ 以上で約 $18 \%, 900^{\circ} \mathrm{C}$ では約 $36 \%, 900^{\circ} \mathrm{C}+$ 水蒸 気では約 $50 \%$ と温度上昇および水蒸気添加に伴っ て大きくなった。本研究における実験系では，液 体成分は水冷して回収しているが，実際の熱分解 炉では，これらの液体成分もガス状で存在してい る可能性がある。従って，(4)-b)における液体成分 による回収熱量を加えた場合, 特に $900^{\circ} \mathrm{C}+$ 水蒸気 においては，乾燥ケーキ低位発熱量の約 $53 \%$ の回 収が期待できる。

\section{4. 結論と今後の課題}

本研究では, 下水污泥の然料化として, 炭化, ガ ス化といった $2 つ の$ 熱分解手法が検討される中, こ れらの技術を位置づけ，適切に選択していくため に，まず，広い温度範囲で下水污泥の熱分解実験 を行って, 熱分解生成物の組成, および発熱量に ついて, 定量的な評価を行なった。 以下に得られ た知見と課題を以下に示した.

(1) 熱分解残渣の収率は熱分解温度の上昇ととも に減少し，300〜 $500^{\circ} \mathrm{C}$ での減少が最大約 $30 \%$ であった。タール分の収率は $500^{\circ} \mathrm{C}$ で最大の $21 \%$ であった。生成ガスの収率は熱分解温度 の上昇とともに増加し， $900{ }^{\circ} \mathrm{C}$ では $15 \%$ 程度， $900^{\circ} \mathrm{C}+$ 水蒸気では $25 \%$ 程度であった。 これら の傾向は，先行研究と同様であり，本実験系 で下水污泥の熱分解が行えていることを確認 した。

(2) 熱分解残渣の低位発熱量は， $300^{\circ} \mathrm{C}$ では乾燥 ケーキとほぼ同程度の約 $15 \mathrm{MJ} / \mathrm{kg}$ であった。回 収熱量としては， $300^{\circ} \mathrm{C}$ では乾燥ケーキの約 $70 \%$ 程度を回収できるが，500 $\mathrm{C}$ 以上では収率 と低位発熱量がともに減少するため，熱分解 残渣の燃料利用としては $300^{\circ} \mathrm{C}$ に比較して不利 となる。
(3) タール分の低位発熱量は28.3〜 31.8MJ/kgであ り, 乾燥ケーキの 2 倍程度であった. 凝縮水も 考慮した液体成分としての回収熱量は 0.42

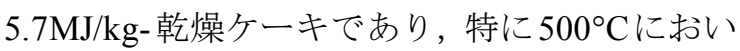
ては乾燥ケーキ熱量の $40 \%$ が液体成分に移行 した.

(4) 生成ガスの低位発熱量は, 温度上昇と水蒸気 の添加に伴い増加し, $900^{\circ} \mathrm{C}$ で $5.00 \mathrm{MJ} / \mathrm{kg}$ - 乾燥 ケーキとなり， $900^{\circ} \mathrm{C}+$ 水蒸気ではガス改質反 応の進行により $7.57 \mathrm{MJ} / \mathrm{kg}$ - 乾燥ケーキとなっ た. 炭化水素類は, $500^{\circ} \mathrm{C}$ 以上で全体の約 50 $80 \%$ に寄与したが, $900^{\circ} \mathrm{C}+$ 水蒸気の条件では, $\mathrm{CO}, \mathrm{H}_{2}$ の寄与が大きくなり, $900^{\circ} \mathrm{C}+$ 水蒸気で の生成ガスの低位発熱量に, 液体成分による 回収熱量を加えた場合は，乾燥ケーキの低位 発熱量に対し，約 $53 \%$ を回収することが見込 める.

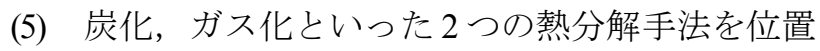
づけ，既存技術である焼却と比較しつつ，適 切に選択していくためには，本研究で明らか とした各温度での熱分解残渣, 液体成分, 生 成ガスへの低位発熱量を基に，投入する熱量， 放熱などの熱損失を考慮した熱収支を把握す るとともに，熱分解残渣を利用する場合には， 石炭火力発電所までの運搬エネルギーや発電 所での発電端効率，生成ガスを利用する際に はガスエンジン発電の発電端効率などを考慮 して, 総合的に判断していく必要がある.

謝辞：本研究を進めるにあたり，ご協力頂きまし た大阪府下水道技術研究会の皆様, 寝屋川北部流 域下水道鴻池水みらいセンターの皆様に深く感謝 いたします。また本研究で行った実験や分析に関 して，ご協力いただきました京都大学大学院工学 研究科技術職員の塩田憲司様, 同研究科都市環境 工学専攻環境デザイン工学講座の学生の皆様に深 く感謝いたします。なお, 本研究の一部は, 京都 大学大学院工学研究科附属桂インテックセンター 内に設置された環境物質制御工学領域高等研究院 で実施された。

\section{参考文献}

1) 那須基:資源のみちとバイオマスのエネルギー利用, 廃棄物学会誌, Vol.18, No.3, pp.155-160, 2007.

2) 椎屋光昭, 上田厚志, 城田猛: 石炭火力発電所に適し た下水污泥然料化技術の開発, 第 44 回下水道研究発 表会講演集，pp.361-363， 2007.

3）亀山寛達: 下水污泥加の発電, 再生と利用, Vol.29, 
No.113, pp.38-42, 2006.

4) 斎賀亮宏, 井藤宗親, 武谷亮: 下水污泥ガス化システ ムの開発, タクマ技報, Vol.11, No.2, pp.135-142, 2003.

5）日本下水道協会：下水試験方法 上巻, pp.296-297, 1997.

6) 日本規格協会 : 石炭類及びコークス類一ボンブ熱量 計による総発熱量の測定方法および真発熱量の計算方 法 JIS M 8814, 2003.

7) 山本博英：下水污泥バイオマス固形燃料化事業の概 要, 資源環境対策, Vol.42, No.5, pp.41-44, 2006.

8) 財団法人下水道新技術推進機構:炭化システム技術資 料, p. $8,2004$.

9) 土木学会環境工学委員会, 環境工学に関わる出版準備 小委員会: 環境工学公式・モデル・数值集, 土木学会, pp.177-179, 2004.
10) 平岡正勝, 高内政彦, 武田信生:下水污泥の熱分解反 応に関寸る研究 (第 1 報), 下水道協会誌, Vol.10, No.109, pp.30-38, 1973.

11) 新井紀男, 林善次, 架谷昌信, 杉山幸男: 余剩活性污 泥の熱分解, 化学工学, Vol.6, No.3, pp.301-306, 1980.

12) 山崎高, 高津宏和, 山形定, 村尾直人, 太田幸雄 : 木 質バイオマス部分酸化ガス化でのタール生成挙動, 第 13 回地球環境シンポジウム講演論文集, 土木学会, pp.225-230, 2005.

13) K. J. Laidler (高石哲男訳) : Reaction Kinetics (I), 化学 反応速度論 (I), 産業図書, p.143, 1965.

(2007.10.15 受付)

\title{
FUNDAMENTAL STUDY ON THE COMPOSITION AND HEATING VALUE OF CHAR, TAR AND GAS FROM SEWAGE SLUDGE PYROLYSIS
}

\author{
Kazuyuki OSHITA, Akihiro MORI, Masaki TAKAOKA, Nobuo TAKEDA, \\ Tadao MATSUMOTO and Akira KITAYAMA
}

\begin{abstract}
Carbonization and gasification processes are being developed in Japan to convert sewage sludge into fuel. It is necessary to tailor these technologies in terms of thermal recovery, local conditions, costs, and hazardous materials. Therefore, we investigated the effect of the pyrolysis temperature on the composition and heating value of char, tar, and gas, and the rate equation for the production of hydrocarbon gas. We were able to recover about $70 \%$ of the low heating value of dry sludge cake as char at $573 \mathrm{~K}$. By contrast, at over $773 \mathrm{~K}$, both the yield and low heating value of char were decreased, and the recovery from char was inefficient. At $1173 \mathrm{~K}$, we were able to recover only about $36 \%$ of the low heating value of dry sludge cake as gas. The production of $\mathrm{H}_{2}$ and $\mathrm{CO}$ was increased with steam, and we were able to recover about $50 \%$ as gas.
\end{abstract}

